\title{
Effect of Different Planting Time on Tomato Yellow Leaf Curl Virus (TYLCV) of Tomato and Its Impact on Yield in Bangladesh
}

\author{
Arman Hasan Anik ${ }^{1}$, Fatema Begum ${ }^{2}$, F. M. Aminuzzaman ${ }^{3}$, Md. Jonaid \\ Hossain $^{4}$, Nishan Chakma ${ }^{5}$ and S. M. Nazmus Sakib Shahin ${ }^{6}$
}

\footnotetext{
${ }^{1 \& 5}$ MS Student, Department of Plant Pathology, Sher-e-Bangla Agricultural University, Dhaka-1207, Bangladesh ${ }^{2 \& 3}$ Professor, Department of Plant Pathology, Sher-e-Bangla Agricultural University, Dhaka-1207, Bangladesh ${ }^{4}$ B. Sc. Ag. (Hons.) student, Faculty of Agriculture, Sher-e-Bangla Agricultural University, Dhaka-1207, Bangladesh

${ }^{6}$ Agricultural Extension Officer, Department of Agricultural Extension, Ministry of Agriculture, Government of the People's Republic of Bangladesh, Dhaka-1207, Bangladesh
}

\begin{abstract}
Tomato yellow leaf curl virus (TYLCV) is infamous for tomato-infecting viruses and causes a huge loss of the yield irrespective of the planting time. So, in order to find out the effect of different planting time on TYLCV disease of tomato and its impact on yield. A study was carried out at the Department of Plant Pathology, Sher-e-Bangla Agricultural University (SAU), Dhaka-1207, Bangladesh during the period of October 2016 to May 2017. Two popular BARI released variety namely BARI Tomato14 and BARI Tomato-16 were used in this study that was transplanted at three different planting times $\left(1^{s} t\right.$ planting time on $1^{\text {st }}$ November $2^{\text {nd }}$ planting time on $15^{\text {th }}$ November and $3^{\text {rd }}$ planting time on $1^{\text {st }}$ December 2016). The lowest percent TYLC disease incidence (12.42\%) and percent disease severity (15.37\%) were found in $3^{\text {rd }}$ planting ( $1^{\text {st }}$ December) in BARI Tomato-16 variety, respectively. Under the present study, considering the percentage of TYLC disease incidence and severity, BARI tomato-16 on $1^{\text {st }}$ December showed better performance comparing others. The $3^{\text {rd }}$ planting ( $1^{\text {st }}$ December) and BARI Tomato-16 variety were found to have the highest yield (77.23 ton/ha) and promising the lowest level of percentage of disease incidence $(12.42 \%)$ and percent disease severity (15.37\%) against TYLCV. A strong positive correlation was obtained between the whitefly population and the percent disease incidence of TYLCV. The whitefly population and the yield of tomato were negatively correlated with each other. The yield was also found significant and negatively correlated with the percentage of TYLCV disease incidence.
\end{abstract}

Keywords-TYLCV, tomato, disease incidence, severity, planting time, yield.

\section{INTRODUCTION}

Tomato (Solanum lycopersicum L.) is a popular vegetable crop in Bangladesh as well as many countries in the world. According to FAO [1], in world vegetable production, it ranks 2nd in the world's vegetable production next to potato. Wilcox et al. [2] studied the significant role of tomato in human nutrition, because of its rich source of lycopene, minerals and vitamins such as ascorbic acid (Vitamin-C) and $\beta$-carotene (Vitamin-A) which are antioxidants and promote good health. About 178 million tons of tomatoes were produced in the world in 2016 among which only 368,121 tons produced in Bangladesh, as reported by FAO [1]. The low yield of tomato in Bangladesh is, however, not an indication of the low yielding potentiality of this crop, but the fact that the lower yield may be attributed to a number of reasons like use of low yielding variety, unavailability of quality seeds of improved varieties, disease infection, improper irrigation and fertilizer management etc. Among the factors Lukyanenko [3] has reported that tomato is susceptible to more than 200 diseases and losses of the yield due to the disease as high as 71-95\%. By all, Tobacco mosaic virus (TMV), Tomato leaf curl virus (TLCV) and Tomato yellow leaf curl virus (TYLCV) caused 80, 90 and 100\% yield loss of tomato, respectively, as investigated by Martelli and Quacquarelli [4].

The Tomato yellow leaf curl virus, better known as TYLCV, has reported to be a major menace, which limits 
the tomato cultivation in all tomato growing areas of the world, as stated by Green and Kalloo [5], Brunt et al. [6] and Kalloo [7]. In Bangladesh, the prevalence of TYLCV was first noted by Akanda [8] and the damage may reach even up to $100 \%$ depending on the varieties and stage of infection. The virus is mechanically non-transmissible, graft transmitted, transmitted by whitefly (Bemisia tabaci) in the field. Since it appeared in epidemic form for the last few years, various strategies have been pursued to control the disease. The efforts have been made to characterize the virus systematically, manage the disease through manipulation of sowing dates, growing seedlings in net house and application of insecticides, as reported by Paul [9], Rahman [10], Gupta [11], Azam [12], Akhter [13] and Sultana [14]. Nevertheless, developing resistant variety is the best option for the control of TYLCV, but none of the tomato varieties cultivated in our country is found to have resistance or tolerance to the virus, as noted by Rahman et al. [15]. Hence, the management of TYLCV in Bangladesh is of immensely important to reduce the crop loss and to minimize the deterioration quality, so that the cultivation of tomato could be profitable for farmers.

As the disease caused heavy loss to tomato in many countries, the development of suitable management practices is of utmost importance. It needs an in-depth investigation of the prevalence of the virus in different tomato varieties, the crop damage with respect to the stage of plant infected by the virus, etc. Considering the importance of the above background, the present research program was designed to know the effect of different planting times on the prevalence of TYLCV and whitefly in tomato.

The proposed research work will be carried out to achieve the following specific objectives:

- To evaluate the incidence and severity of Tomato yellow leaf curl virus (TYLCV) against two popular cultivars of tomato.

- To find out a suitable planting time of tomato for the reduction of TYLCV incidence.

- To see the effect of Tomato yellow leaf curl disease on the impact of the yield of tomato.

\section{MATERIALS AND METHODS}

The experiment was conducted at the research field of Sher-e-Bangla Agricultural University, Sher-e-Bangla Nagar, Dhaka-1207. For fulfilling the objectives of the experiment, the seeds of BARI Tomato-14 (2007) and BARI Tomato-16 (2015) were collected from Vegetable Division, Horticulture Research Centre (HRC), BARI,
Joydebpur, Gazipur-1701, Bangladesh. Later the seeds were raised in 6 seedbeds of $1 \mathrm{Sq}$. Meter and 10grams of each variety's seeds were sown in the seedbed on 01st October 2016, 15th October 2016, and 01st November 2016 as $1^{\text {st }}, 2^{\text {nd }}$, and $3^{\text {rd }}$ planting time respectively. After sowing, seeds were then covered with finished light soil. Then light watering, shading, weeding, and mulching were done as necessary to provide seedlings a good environment for vigorous growth and development. The field was plowed, cross-plowed, cleaned, leveled, Furadan10G application for controlling soil-borne pathogen and fertilizer application (as per recommended dose by BARI, 2005) were done in a sequential manner.

The layout of the experiment was laid out in a Randomized Complete Block Design (RCBD) with three replications. The experimental site was refuted into 3 blocks each containing 6 plots of $2.45 \mathrm{~m} \times 2.30 \mathrm{~m}$ in size, having a total of 18 plots. The drain was kept $1.0 \mathrm{~m}$ between the blocks and $0.5 \mathrm{~m}$ between the plots. The distance between row to row and plant to plant was $65 \mathrm{~cm}$ and $60 \mathrm{~cm}$, respectively. Healthy and uniform seedlings were transplanted in the experimental plot allowing an accommodation of 16 plants per plot.

In the field, intercultural operations like irrigation, drainage, stalking, weeding, top-dressing, etc. were accomplished to enhance the growth and development of the tomato seedlings. Fruits were harvested at 5 days intervals during maturity to ripening stage started from 20th February 2017 and completed by 30th May 2017. The identification of Tomato Yellow Leaf Curl Virus (TYLCV) was based on typical field symptoms as described by Akanda [8], Alam [16], and Gupta [11]. The plants were inspected at 20,30,40,50, and 60 DAT to observe the appearance and development of the symptoms of TYLCV at three planting time (Figure 1).

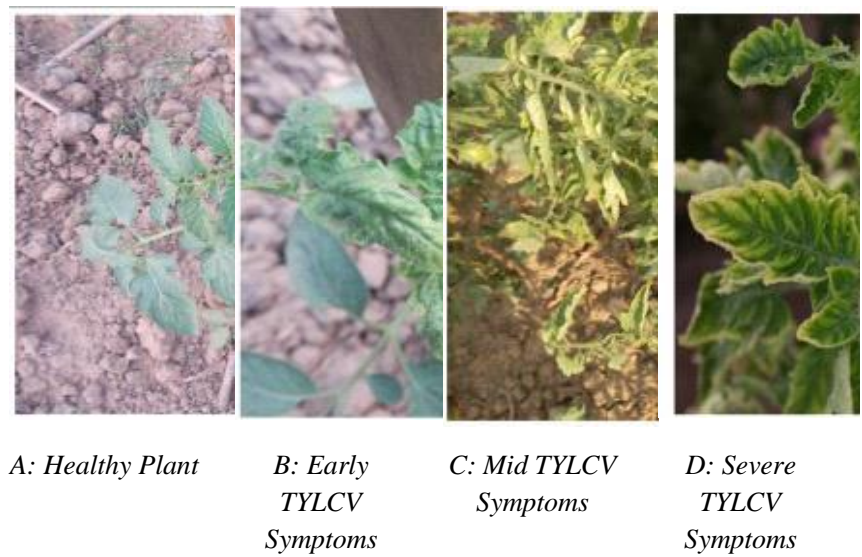

Fig. 1: (A) Healthy Tomato Plant, (B-D) TYLCV Symptoms at Tomato Plant 
Collecting data on the following parameters-

- Number of leaves/plant

- $\quad$ Number of infected leaves/plant

- $\quad$ Number of infected plants

- $\quad$ Number of branch/plant

- Number of flowers/plant

- Number of fruits/plant

- $\quad$ Fruit weight/plant (kg)

- $\quad$ Fruit weight/plot $(\mathrm{kg})^{*}$

- $\quad$ Plant height $(\mathrm{cm})$

- $\quad$ Fruit yield (kg/ha)

All these entities were documented from 20, 30, 40, 50, and 60 DAT for better observation of the occurrences.

As for Disease Incidence (\%), the calculation was followed by the formula which was used by Ashrafuzzaman [17]:

$\begin{gathered}\text { Number of diseased } \\ \text { plant /leaves }\end{gathered}$
Disease Incidence $(\%)=----------------x 100$
Number of total
plants/leaves observed

Likewise, the Disease Severity (\%) was calculated using the following formula which was used by Ashrafuzzman [17]:

$\begin{gathered}\text { Amount of tissue } \\ \text { infected }\end{gathered}$
Disease Severity $(\%)=-----------------$ x 100
Total area inspected

The scaling was done based on the Disease Rating Scale given by Ali et al. [18].

Table-1: Disease Rating Scale of TYLCV

\begin{tabular}{|l|l|c|}
\hline Rating & Scale & $\begin{array}{c}\text { Severity Range } \\
(\%)\end{array}$ \\
\hline 0 & Immune & 0 \\
\hline 1 & Highly Resistant & $1-10$ \\
\hline 2 & Moderate Resistant & $11-25$ \\
\hline 3 & Tolerant & $26-50$ \\
\hline 4 & Moderate Susceptibility & $51-60$ \\
\hline 5 & Susceptibility & $61-70$ \\
\hline 6 & High Susceptibility & $71-100$ \\
\hline
\end{tabular}

Source: Ali et al., (2005)

ISSN: 2456-1878

https://dx.doi.org/10.22161/ijeab.54.10
The data obtained for different characters were statistically analyzed using MSTAT-C software. To calculate the level of significant difference and to separate the means within the parameters Duncan's Multiple Range Test (DMRT) and Least Significant Difference (LSD) test were performed at a 5\% level of significance. Graphs and charts were also done to see the interpretation of different parameters.

\section{RESULTS}

1. Effect of planting time on disease incidence (\%) and disease severity (\%) of TYLCV between tomato varieties

There were significant differences found among different planting times between two tomato varieties as shown in table 2. The TYLCV disease incidence $(\%)$ ranged from 12.417 to 76.833 among three planting time. The highest TYLCV incidence was observed on $1^{\text {st }}$ November in BARI Tomato-14 (76.833\%) followed by BARI Tomato-16 $(62.50 \%)$. Then again, the lowest TYLCV incidence (\%) was found in the $1^{\text {st }}$ December planting time in BARI Tomato-16 (12.417) followed by the same planting time in BARI Tomato-14 (21.67). On the other hand, TYLCV severity (\%) ranged from 15.370 to 69.217 . The highest TYLCV severity (\%) was observed in $1^{\text {st }}$ November in BARI Tomato-14 (69.217) followed by BARI Tomato-16 (57.193) and the lowest TYLCV severity (\%) was found in $1^{\text {st }}$ December in BARI Tomato-16 (15.370) followed by same planting time in BARI Tomato-14 (23.557).

Table-2: Effect of Three Planting Time on TYLCV Disease Incidence (\%) and Disease Severity (\%) Between Two Varieties

\begin{tabular}{|c|c|c|c|}
\hline Treatment & Variety & $\begin{array}{c}\text { Disease } \\
\text { Incidence } \\
(\%)\end{array}$ & $\begin{array}{c}\text { Disease } \\
\text { Severity } \\
(\%)\end{array}$ \\
\hline \multirow[t]{2}{*}{$\begin{array}{c}1^{\text {st }} \\
\text { November }\end{array}$} & $\begin{array}{c}\text { BARI } \\
\text { Tomato-14 }\end{array}$ & $76.833 \mathrm{a}^{*}$ & $69.217 \mathrm{a}$ \\
\hline & $\begin{array}{c}\text { BARI } \\
\text { Tomato-16 }\end{array}$ & $62.500 \mathrm{~b}$ & $57.193 \mathrm{~b}$ \\
\hline \multirow[t]{2}{*}{$\begin{array}{c}15^{\text {th }} \\
\text { November }\end{array}$} & $\begin{array}{c}\text { BARI } \\
\text { Tomato-14 }\end{array}$ & $39.333 \mathrm{c}$ & $42.050 \mathrm{c}$ \\
\hline & $\begin{array}{c}\text { BARI } \\
\text { Tomato-16 }\end{array}$ & $30.000 \mathrm{~cd}$ & $35.283 \mathrm{~d}$ \\
\hline \multirow[t]{2}{*}{$\begin{array}{c}1^{\text {st }} \\
\text { December }\end{array}$} & $\begin{array}{c}\text { BARI } \\
\text { Tomato-14 }\end{array}$ & $21.667 \mathrm{de}$ & $23.557 \mathrm{e}$ \\
\hline & $\begin{array}{c}\text { BARI } \\
\text { Tomato-16 }\end{array}$ & $12.417 \mathrm{e}$ & $15.370 \mathrm{f}$ \\
\hline
\end{tabular}


International Journal of Environment, Agriculture and Biotechnology, 5(4)

Jul-Aug, 2020 / Available: https://ijeab.com/

\begin{tabular}{ccc}
\hline LSD (0.05) & 10.006 & 5.7692 \\
\hline CV (\%) & 8.74 & 5.04 \\
\hline
\end{tabular}

*Means followed by same letters not significantly different at $5 \%$ level by LSD

2. Effect of growth characters due to Tomato yellow leaf curl virus (TYLCV) disease infection between two tomato varieties

Growth contributing characters were affected due to TYLCV infection at three planting time between two tomato varieties. The effects of growth and growth contributing characters due to TYLCV are shown in table 3. The maximum number of leaves per plant (80.33) was observed at $2^{\text {nd }}$ and $3^{\text {rd }}$ planting time in BARI Tomato- 16 followed by $1^{\text {st }}$ planting in the same variety (79.00). Whereas, the minimum number of leaves/plant (73.67) was found in $1^{\text {st }}$ planting ( $1^{\text {st }}$ November) in BARI Tomato-14. The highest number of branch/plant (10.667) was observed at $3^{\text {rd }}$ planting in BARI Tomato-16 followed by BARI Tomato-14 (79.000). The lowest number of branch/plant (5.333) was found at $1^{\text {st }}$ planting in BARI Tomato-14. In the case of the number of flower number per plant, the maximum number of flower/plant (76.000) was observed in $3^{\text {rd }}$ planting in BARI Tomato-16 followed by $2^{\text {nd }}$ planting in BARI Tomato-16 (70.000). The minimum number of flower/plant (41.000) was found in $1^{\text {st }}$ planting in BARI Tomato-14 followed by BARI Tomato-16 (54.333) in the same planting. Likewise, the plant height ranged from $68.167 \mathrm{~cm}$ to $95.200 \mathrm{~cm}$, while the tallest plant $(95.200 \mathrm{~cm})$ was found in $3^{\text {rd }}$ planting in BARI Tomato-14 followed by the same planting time in BARI Tomato-16 $(88.767 \mathrm{~cm})$. The lowest plant height $(68.167$ $\mathrm{cm})$ was recorded in $1^{\text {st }}$ planting of BARI Tomato-16 variety followed by BARI Tomato-14 $(73.800 \mathrm{~cm})$ variety.

Table-3: Effect of Three Planting Time on Growth and Growth Contributing Character Between Two Tomato Varieties Against Tomato Yellow Leaf Curl Virus (TYLCV)

\begin{tabular}{|c|c|c|c|c|c|}
\hline Treatment & Variety & $\begin{array}{c}\text { Leaves/ plant } \\
\text { (No.) }\end{array}$ & $\begin{array}{c}\text { Branch/ } \\
\text { plant } \\
\text { (No.) }\end{array}$ & $\begin{array}{c}\text { Flower/ } \\
\text { plant } \\
\text { (No.) }\end{array}$ & $\begin{array}{l}\text { Plant height } \\
\text { (cm) }\end{array}$ \\
\hline \multirow{2}{*}{$\begin{array}{l}1^{\text {st }} \text { November } \\
\left(1^{\text {st }} \text { Planting }\right)\end{array}$} & BARI Tomato-14 & $73.667 \mathrm{~b}^{*}$ & $5.333 \mathrm{~d}$ & $41.000 \mathrm{e}$ & $73.800 \mathrm{e}$ \\
\hline & BARI Tomato-16 & $79.000 \mathrm{a}$ & $5.667 \mathrm{~b}$ & $54.333 \mathrm{~d}$ & $68.167 \mathrm{f}$ \\
\hline \multirow{2}{*}{$\begin{array}{l}15^{\text {th }} \text { November } \\
\left(2^{\text {nd }} \text { Planting) }\right.\end{array}$} & BARI Tomato-14 & $75.333 \mathrm{~b}$ & $7.667 \mathrm{c}$ & $57.000 \mathrm{~cd}$ & $84.500 \mathrm{c}$ \\
\hline & BARI Tomato-16 & $80.333 \mathrm{a}$ & $8.667 \mathrm{bc}$ & $70.000 \mathrm{~b}$ & $78.933 \mathrm{~d}$ \\
\hline \multirow{2}{*}{$\begin{array}{l}1^{\text {st }} \text { December } \\
\left(3^{\text {rd }} \text { Planting }\right)\end{array}$} & BARI Tomato-14 & $75.333 \mathrm{~b}$ & $10.333 \mathrm{ab}$ & $60.667 \mathrm{c}$ & $95.200 \mathrm{a}$ \\
\hline & BARI Tomato-16 & $80.333 \mathrm{a}$ & $10.667 \mathrm{a}$ & $76.000 \mathrm{a}$ & $88.767 \mathrm{~b}$ \\
\hline \multicolumn{2}{|r|}{$\mathbf{L S D}_{(0.05)}$} & 2.5323 & 1.6882 & 4.2937 & 2.5141 \\
\hline \multicolumn{2}{|r|}{ CV $(\%)$} & 1.16 & 7.40 & 2.53 & 1.09 \\
\hline
\end{tabular}

*Means followed by same letters not significantly different at 5\% level by LSD

3. Effect of yield and yield characters due to Tomato yellow leaf curl virus (TYLCV) disease infection between two tomato varieties

Yield and yield contributing characters of the tomato were affected due to TYLCV infection at different planting times. The effects of the yield and yield contributing characters due to TYLCV are shown in table 4 . The highest ISSN: 2456-1878 number of fruits per plant (40.00) was observed in $3^{\text {rd }}$ planting in BARI Tomato-16 followed by $2^{\text {nd }}$ planting in BARI Tomato-16 (37.333) and the lowest number of fruits/plant (21.333) was found in $1^{\text {st }}$ planting in BARI Tomato-14 followed by same planting time in BARI Tomato-16 (28.333). As for the range of fruit 
weight/plant, the maximum fruit weight/plant $(2.72 \mathrm{~kg})$ was observed in $3^{\text {rd }}$ planting in BARI Tomato-16 followed by BARI Tomato-14 $(2.52 \mathrm{~kg})$ and the minimum fruit weight/plant $(1.6667 \mathrm{~kg})$ was found in $1^{\text {st }}$ planting of BARI Tomato-14 followed by same planting time in BARI Tomato-16 $(1.9267 \mathrm{~kg})$. Fruit yield between two tomato varieties at three planting, the highest fruit yield (43.52 $\mathrm{kg} / \mathrm{plot}=77.23$ ton $/ \mathrm{ha}$ ) was found in $3^{\text {rd }}$ planting in BARI Tomato-16 followed by $2^{\text {nd }}$ planting in BARI Tomato-16 $(40.64 \mathrm{~kg} / \mathrm{plot}=72.12 \mathrm{ton} / \mathrm{ha})$. On the contrary, the lowest fruit yield was recorded in $1^{\text {st }}$ planting in BARI Tomato-14 $(26.667 \mathrm{~kg} / \mathrm{plot}=47.32 \mathrm{ton} / \mathrm{ha})$ followed by the same planting time in BARI Tomato-16 $(30.827 \mathrm{~kg} / \mathrm{plot}=54.71$ ton/ha).

Table-4: Effect of Different Planting Time on Yield and Yield Contributing Character between Two Tomato Varieties against Tomato Yellow Leaf Curl Virus (TYLCV)

\begin{tabular}{|c|c|c|c|c|c|}
\hline Treatment & Variety & $\begin{array}{c}\text { Fruits/ plant } \\
\text { (No.) }\end{array}$ & $\begin{array}{c}\text { Fruit weight/ } \\
\text { plant } \\
(\mathrm{Kg})\end{array}$ & $\begin{array}{c}\text { Yield } \\
\text { (kg/plot) }\end{array}$ & $\begin{array}{c}\text { Fruit yield } \\
\text { (ton/ha) }\end{array}$ \\
\hline \multirow[t]{2}{*}{$\begin{array}{l}1^{\text {st }} \text { November } \\
\left(1^{\text {st }} \text { Planting }\right)\end{array}$} & $\begin{array}{c}\text { BARI Tomato- } \\
14\end{array}$ & $21.333 \mathrm{e}^{*}$ & $1.6667 \mathrm{e}$ & 26.667 e & $47.323 \mathrm{e}$ \\
\hline & $\begin{array}{l}\text { BARI Tomato- } \\
16\end{array}$ & $28.333 \mathrm{~d}$ & $1.9267 \mathrm{~d}$ & $30.827 \mathrm{~d}$ & $54.706 \mathrm{~d}$ \\
\hline \multirow[t]{2}{*}{$\begin{array}{l}15^{\text {th }} \text { November } \\
\left(2^{\text {nd }} \text { Planting) }\right.\end{array}$} & $\begin{array}{l}\text { BARI Tomato- } \\
14\end{array}$ & $29.667 \mathrm{~d}$ & $2.3133 \mathrm{c}$ & $37.013 \mathrm{c}$ & $65.685 \mathrm{c}$ \\
\hline & $\begin{array}{l}\text { BARI Tomato- } \\
16\end{array}$ & $37.333 \mathrm{~b}$ & $2.5400 \mathrm{~b}$ & $40.640 \mathrm{~b}$ & $72.121 \mathrm{~b}$ \\
\hline \multirow[t]{2}{*}{$\begin{array}{l}1^{\text {st }} \text { December } \\
\left(3^{\text {rd }} \text { Planting }\right)\end{array}$} & $\begin{array}{l}\text { BARI Tomato- } \\
14\end{array}$ & $32.333 \mathrm{c}$ & $2.5200 \mathrm{~b}$ & $40.320 \mathrm{~b}$ & $71.553 \mathrm{~b}$ \\
\hline & $\begin{array}{l}\text { BARI Tomato- } \\
16\end{array}$ & $40.000 \mathrm{a}$ & $2.7200 \mathrm{a}$ & $43.520 \mathrm{a}$ & $77.232 \mathrm{a}$ \\
\hline $\operatorname{LSD}_{(0.05)}$ & & 2.0020 & 0.1456 & 2.3300 & 4.1351 \\
\hline CV (\%) & & 2.24 & 2.25 & 2.25 & 2.26 \\
\hline
\end{tabular}

*Means followed by same letters not significantly different at $5 \%$ level by LSD

\section{Relation between average whitefly population and TYLCV disease incidence $(\%)$}

The relationship between the whitefly population and disease incidence (\%) of TYLCV in the field is shown in figure 2. A strong positive correlation exists between the incidence (\%) of TYLCV infection and the whitefly population. It means that with the rise of the whitefly population, TYLCV infection also increases. A regression line was fitted between the whitefly population and \% incidence of TYLCV. The correlation coefficient (r) was $0.9435227^{* *}$ and the contribution of the regression $(\mathrm{R} 2=$ 0.8902 ) indicated that $89.02 \%$ TYLCV infection increased by whitefly.

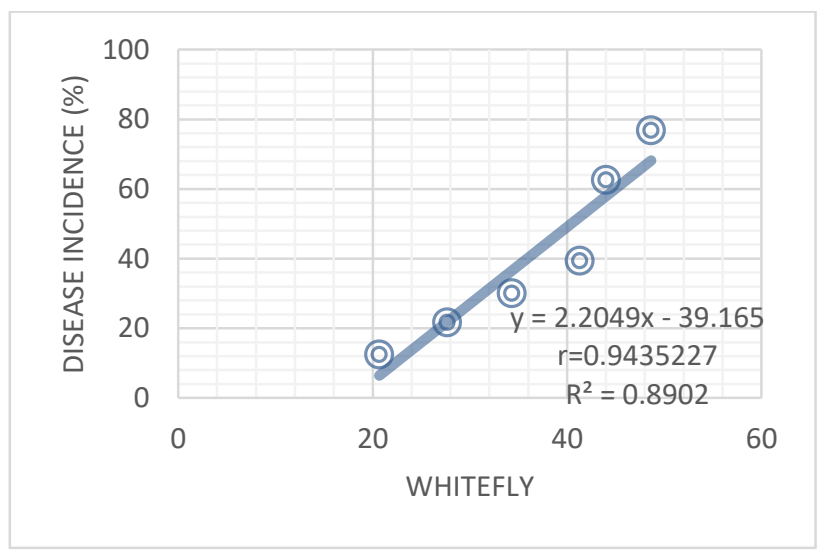

Fig.2: Relation Between Whitefly Populations Build up and $\%$ TYLCV Incidence 


\section{Relation between TYLCV disease incidence (\%) and yield (ton/ha) of tomato}

A significant negative correlation was found between the incidence of TYLCV (\%) and the yield of tomato is shown in figure 3. It means that with the increase of incidence of TYLCV (\%), the yield of tomato reduced. A regression line was fitted between $\%$ incidence of TYLCV and the yield of tomato. The correlation coefficient (r) was $0.991826366^{* *}$ and the contribution of the regression $\left(\mathrm{R}^{2}=\right.$ 0.9837 ) indicates that $98.37 \%$ yield in tomato would be affected by TYLCV infection.

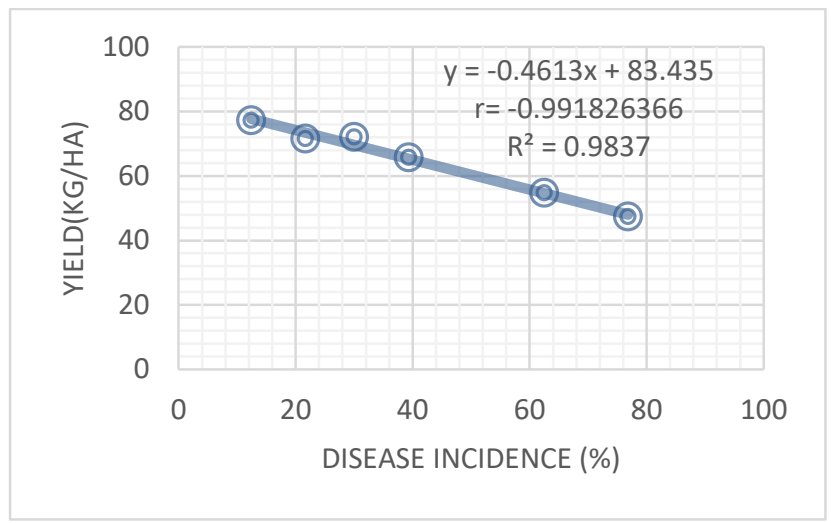

Fig.3: Relation Between Incidence of TYLCV (\%) and Yield of Tomato

\section{Relation between average whitefly population and yield (ton/ha) of tomato}

Following a negative correlation was found between the whitefly population and yield of tomato is shown in figure 4. This indicates that with the rise of the whitefly population, the yield of tomato decreased. A regression line was fitted between the whitefly population and yield of tomato. The correlation coefficient ( $r$ ) was $-0.913954412 * *$ and the contribution of the regression $\left(\mathrm{R}^{2}=0.8353\right)$ indicates that $83.53 \%$ yield in tomato would be affected by whitefly.

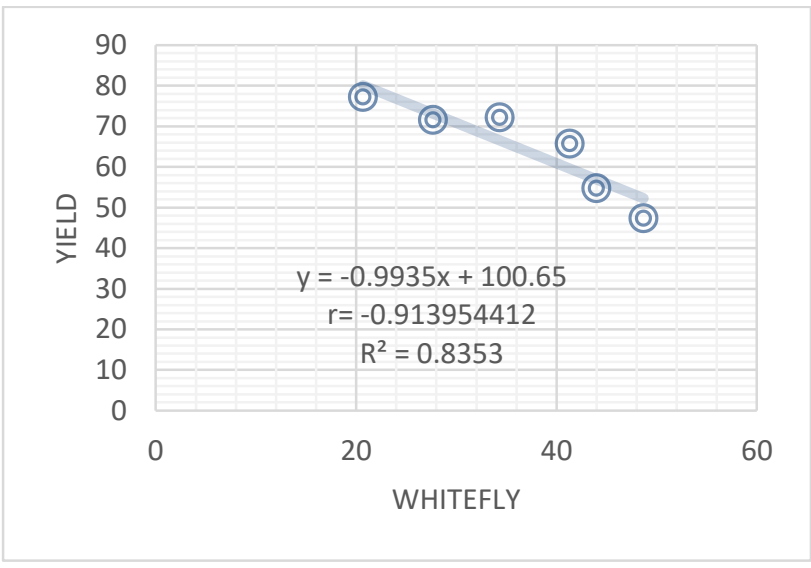

Fig.4: Relation Between Whitefly Population and Yield of Tomato

\section{DISCUSSION}

Tomato (Solanum lycopersicum) belongs to the Solanaceae family which is a popular vegetable crop in Bangladesh as well as many countries around the world. Among the virus diseases of tomato, TYLCV is the major one with respect to prevalence, severity, and damage to the crop in all tomato growing areas in the world which alone could cause $100 \%$ yield loss of the crop. To study the effect of different planting time on Tomato yellow leaf curl virus (TYLCV) and its impact on the yield of tomato a field experiment was conducted at the Research farm of Sher-e-Bangla Agricultural University, Dhaka, during the Rabi season from October' 2016 to March' 2017. There were two factors in the experiment comprising three levels of planting time $\left(1^{\text {st }}\right.$ November $15^{\text {th }}$ November and $1^{\text {st }}$ December) and two levels of variety as BARI Tomato-14 and BARI Tomato- 16.

\section{Effect of TYLCV disease incidence (\%) and severity (\%) between tomato varieties}

The results of the present study indicated that tomato yield was seriously affected by the date of planting because it has a high sensitivity towards temperature for fruit set. High temperature brings down fruit setting and ultimately effect on yield. So, during flowering time tomato needs optimum temperature for better yield. As we get that, the $3^{\text {rd }}$ planting ( $1^{\text {st }}$ December planting) and the BARI Tomato16 between two varieties performed better in the case of TYLCV disease incidence (12.417\%) and severity $(15.37 \%)$. On the other hand, the highest TYLCV disease incidence $(76.833 \%)$ and severity $(69.217 \%)$ was found in $1^{\text {st }}$ planting of BARI Tomato-14. Almost such type of investigation on different planting time and varietal performance against the TYLCV disease incidence (\%) and severity (\%) in tomato field was obtained by Mazyad et al. [19], Pilowsky et al. [20], Gupta [11], Azam [12], Paul[9] and Rashid et al. [21].

\section{Outcome of yield and growth of tomatoes on three planting time}

Likewise, the highest number of branch/plant (10.67), fruit/plant (40.00), flower/plant (76.00), fruit weight/plant $(2.72 \mathrm{Kg})$, fruit yield $(77.23 \mathrm{ton} / \mathrm{ha})$ was observed in $3^{\text {rd }}$ planting of BARI Tomato-16 and as for the lowest number of branch/plant (5.33), fruit/plant (21.33), flower/plant (41.00), fruit weight/plant $(1.67 \mathrm{Kg})$, fruit yield (47.32 ton/ha) was recorded in $1^{\text {st }}$ planting of BARI Tomato- 14. These results go in agreement with Sinisterra et al. [22] findings which signify that branch number reduced more in the early planting than the late planting and the fruits number reduced more in the early planting than the late planting due to TYLCV infection. In agreement with Gupta 
[11], the late planting produced more flowers than the early planting. The late planting had more fruit weight/plant than the early planting and the higher severity of TYLCV was one of the reasons for reduction of fruit yield in tomato plants, in agreement with Lukyanenko [3] and Polston et al. [23] as they reported that TYLCV is caused a reduction of the yield and pointed out that TYLCV transmitted by whitefly is the most serious disease of tomato in tropical and subtropical Asian countries and parts of Africa, respectively. The highest number of leaves/plant (80.333) was observed in the $2^{\text {nd }}$ planting of BARI Tomato-16 and the lowest number of leaves/plant (73.667) was found in $1^{\text {st }}$ planting in BARI Tomato-14. From this result, it can be concluded that the number of leaves/plants reduced more in the early planting compared to the late planting. However, the tallest plant $(95.20 \mathrm{~cm})$ was found in the $3^{\text {rd }}$ planting of BARI Tomato-14 and the lowest plant height $(68.167 \mathrm{~cm})$ was recorded in the $1^{\text {st }}$ planting of BARI Tomato-16. This result indicated that there were significant differences between the late planting and the early planting. Results indicated that the late planting obtained maximum heights than the early planting these types of findings were also reported by Rahman [10]. The results indicated that the yield of tomato was positively influenced by the number of leaves, number of flowers, plant height, number of fruits, fruit weight. The results of the study agree with the findings of Mohanty [24-26].

The highest number of whiteflies per plant (48.667) was observed in the $1^{\text {st }}$ planting of BARI Tomato-14. The lowest number of whitefly/plant (20.667) was found in the $3^{\text {rd }}$ planting of BARI Tomato-16. The results of this present study revealed that the whitefly number reduced more in the late planting than the early planting. Verma et al. [27] stated that the incidence of TYLCV on tomato was directly related to the population density of the vector developed when the incidence of the disease also began to increase. The increase of the whitefly population was also found to be positively correlated with the spread of TYLCV in the field as reported by Mehta et al. [28], Gupta [11], and Paul [9].

Cohen and Nitzany [29] reported that TYLCV shows great regional and seasonal variations mainly because of fluctuations in the population density of the whitefly vector. For this, the relationship between the whitefly population and incidence of TYLCV was investigated. A positive correlation between the incidence of TYLCV and 46 whitefly population (0.9435227) was recorded which was supported by Saikia and Muniyappa [30], Polizzi et al. [31] and Aboul-Ata et al. [32]. The present study also revealed the relationship between the whitefly population and yield of tomato. A negative correlation $(\mathrm{r}=$ -
0.913954412 ) between the whitefly population and yield of tomato was recorded which is an accordance with the findings of Gupta [11]. A negative correlation ( $\mathrm{r}=$ 0.991826366) between the incidence of TYLCV and the yield was also obtained that has also been supported by Gupta [11].

\section{CONCLUSION}

The results indicated that the percentage of TYLCV disease incidence and disease severity was lowest in $3^{\text {rd }}$ planting ( $1^{\text {st }}$ December) of BARI Tomato-16 variety. It also indicated that higher incidence and severity of TYLCV were one of the reasons for the reduction of fruit yield in tomato plants which are greatly dependent on planting time. Not to mention, among all the $3^{\text {rd }}$ planting of BARI Tomato-16 varieties had maximum growth and growth contributing characters like as the number of leaves, branch flower, and plant height, indicated that the yield of tomato was increased by a number of leaves, branch flower, and plant height. As for yield and yield contributing characters like as number of fruits, fruit weight/plant, fruit yield ( $\mathrm{kg} / \mathrm{plot})$, fruit yield $(\mathrm{kg} / \mathrm{ha})$, and fruit yield (ton/ha) were highest in the $3^{\text {rd }}$ planting of BARI Tomato-16 varieties.

Other results also revealed that the whitefly population reduced more in the late planting than the early planting showing a positive correlation between the whitefly population and disease incidence $(\%)$ of TYLCV $(0.9435227 * *)$ with temperature. A negative correlation $(\mathrm{r}$ $\left.=-0.991826366^{* *}\right)$ between the incidence of TYLCV and yield was also obtained in this study giving us a negative correlation $(\mathrm{r}=-0.913954412 * *)$ between the whitefly population and yield of tomato was also recorded. Considering the outcome of the study, there is still a need for a resistant variety and better cultural management to inhibit the growth of the disease and for farmers, late planting is the best to get high yield amid the TYLCV.

\section{REFERENCES}

[1] FAO., 2016. FAOSTAT database. Food and Agriculture Organization of the United Nations, Geneva. http://www.fao.org/faostat/en/\#data/QC/visualize.

[2] Willcox, J.K., Catignani, G.L. and Lazarus, S. 2003. Tomatoes and cardiovascular health. Critical Reviews in Food Science and Nutrition, 43(1). pp.1-18.

[3] Lukyanenko, A.N. 1991. Disease Resistance in Tomato. In: Kalloo, G. (Ed.). Genetic Improvement of Tomato. 14, Monographs on Theoretical and Applied Genetics, Germany: Springer-Verlag Berlin Heidelberg, pp. 99-119. 
[4] Martelli, G.P. and Quacquarelli, A. 1983. The present status of tomato and pepper viruses. Acta Horticulture, 127, pp.3964.

[5] Green, S. K. and Kalloo, G. 1994. Leaf curl and yellowing viruses of pepper and tomato: an overview. Technical Bulletin No. 21. Asian Vegetable Research and Development Center, Taiwan. p.51.

[6] Brunt, A., Crabtree K., and Gibbs. A. (Edt.). 1990. Tomato yellow leaf and Gemini virus. In: Viruses of Tropical Plants. CAB International, Wallingford, Oxon, OX-10 eight DE, UK., pp. 578-580.

[7] Kalloo, G. (Ed.). 1991. Genetic Improvement of Tomato Series: Monographs on Theoretical and Applied Genetics. Germany: Springer-Verlag Berlin Heidelberg.

[8] Akanda, A.M. 1991. Studies on the virus and mycoplasma disease of vegetable crops in Bangladesh. A thesis for the partial fulfillment of Doctor of Agriculture. Submitted to the Plant Pathology Laboratory. Department of Agronomy, Faculty of Agriculture, Kyushu University, Fukuoka, Japan. p.181.

[9] Paul, S.K. 2002. Management of TYLCV in respect to growth and yield of tomato using net house grown seedlings and insecticidal spray. A thesis submitted to the Department of Plant Pathology, BSMRAU, Gazipur-1706 for the partial fulfillment of M.S. in Plant Pathology.

[10] Rahman, A. H. M. A. 2003. Growth and yield performance of eight tomato varieties infected with Tomato yellow leaf curl virus (TYLCV) under field condition. An MS thesis submitted to the Department of Plant Pathology, BSMRAU, Salna, Gazipur, Bangladesh. p.140.

[11] Gupta, N.D. 2000. Occurrence of Tomato yellow leaf curl virus (TYLCV) and Tomato purple vein virus (TPVV) and their effect on growth and yield of tomato. M.S. Thesis, Department of Plant Pathology, BSMRAU.

[12] Azam, M. R. 2001. Prevalence and effect of Tomato yellow leaf curl virus (TYLCV) on growth and yield of net house grown seedlings of tomato. M.S. Thesis, Department of Plant Pathology, BSMRAU, Gazipur. p.69.

[13] Akhter, K. 2003. Effect of date of sowing on the prevalence of Tomato yellow leaf curl virus (TYLCV) and impact of TYLCV infection on growth and yield contributing characters of tomato varieties. An M.S. Thesis submitted to the Department of Plant Pathology, BSMRAU, Gazipur1706.

[14] Sultana, N. A. 2001. An investigation to some aspects of TYLCV and TPVV infecting tomato. An MS thesis submitted to the Department of Plant Pathology, BSMRAU, Salna, Gazipur, Bangladesh. p.90.

[15] Rahman, A.H.M.A., Akanda, A.M. and Alam, A.K.M. 2008. Relationship of Whitefly Population Build up with the Spread of TYLCV on Eight Tomato Varieties. Journal of Agriculture and Rural Development, 4(1 \& 2). pp. 67-74.

[16] Alam, N. 1995. Studies on the virus diseases of tomato in Bangladesh. An M. Phil thesis submitted to the Department of Botany, Jahangirrnagar University, Savar, Dhaka. pp. 5477.
[17] Ashrafuzzaman, 2016. Management of early blight of tomato through different botanical and chemical fungicides. An M.S. Thesis submitted to the Department of Plant Pathology, SAU, Dhaka-1207.

[18] Ali, S., Khan, M.A., Habib, A., Rasheed, S. and Iftikhar, Y. 2005. Correlation of environmental conditions with Okra yellow vein mosaic virus and Bemisia tabaci population density. International Journal of Agriculture and Biology, 7(1). pp. 142-144.

[19] Mazyad, H.M. Omar, F., Al-Taher, K. and Salha. M. 1979. Observations on the epidemiology of Tomato yellow leaf curl virus disease on tomato plants. Plant Disease Reporter, 63(8). pp. 695-698.

[20] Pilowsky M., Cohen S., Ben-Joseph R. and Nahon S., 1993. Effect of Tomato yellow leaf curl virus on tolerant and susceptible cultivars. Proceedings of the XIIth Eucarpia meeting on tomato genetics and breeding, Plovdiv, Bulgaria, 27-31 July 1993, pp. 31-32.

[21] Rashid M. H., Hossain I., Hannan A., Uddin S. A. and Hossain M. A. 2008. Effect of Different Dates of Planting Time on Prevalence of Tomato yellow leaf curl virus and Whitefly of Tomato, Journal of Soil and Nature, 2(1). pp. 16.

[22] Sinistera, X., Patte, C.P., Siewnath, S. and Polston, J.E. 2000. Identification of TYLCV-Is in the Bahamas. Plant Disease, 84(5). p. 592.

[23] Polston, J. E., McGovern, R. J., Sherwood, T. and Kelly, R. 1999. New developments in Tomato yellow leaf curl virus in Florida. In: 1999 Proceedings of the Florida Tomato Institute, Naples, FL, USA, PRO-516. Gainesville, FL, USA: University of Florida, IFAS, pp. 2-5.

[24] Mohanty, B.K. 2002a. Variability, heritability, correlation and path coefficient studies in tomato. Haryana Journal of Horticultural Sciences, 31(3-4). pp. 230-233.

[25] Mohanty, B.K. 2002b. Studies on variability, heritability, interrelationship and path analysis in tomato. Annals of Agricultural Sciences, 23 (1). pp. 65-69.

[26] Mohanty, B.K. 2003. Genetic variability, correlation and path coefficient studies in tomato. Indian Journal of Agricultural Research, 37(1). pp. 68-71

[27] Verma. A.K., Basu, D., Nath, P.S., Das. S., Ghatak. S.S. and Muthapadhayak. S. 1989. Relationship between the population of whitefly, Bemisia tabaci and the incidence of Tomato yellow leaf curl virus. Indian J. of Myco. Res. Plant Virus Research Centre, Department of Plant Pathology. Bidhan Chandra Krishi Viswsvidyalaya, Kalyani, West Bengal.

[28] Mehta, P., Wyman, J.A., Nakhla, M.K. and Maxwell, D.P. 1994. Transmission of Tomato yellow leaf curl geminivirus by Bemisia tabaci (Homoptera: Aleyrodidae). Journal of Economic Entomology, 87(5). pp. 1291-1297.

[29] Cohen, S. and Nitzany, F.E. 1966. Transmission and host range of the Tomato yellow leaf curl virus. Phytopathology, 56. pp. 1127-1131.

[30] Saikia, A.K. and Muniyappa, V. 1989. Epidemiology and control of Tomato leaf curl virus in Southern India. Tropical Agriculture, (Trinidad and Tobago), 66(4). pp. 350-354. 
International Journal of Environment, Agriculture and Biotechnology, 5(4)

Jul-Aug, 2020 / Available: https://ijeab.com/

[31] Polizzi, G. and Asero, C. 1994. Epidemiology and incidence of Tomato yellow leaf curl virus (TYLCV) in green house protected by screen in Italy. Acta Horticulture, 366. pp. 345352.

[32] Aboul-Ata, A. E., Awad, M. A. E., Abdel-Aziz, S., Peters, D., Megahed, H., and Sabik, A. 2000. Epidemiology of Tomato yellow leaf curl begomovirus in the Fayium area, Egypt. EPPO Bulletin, 30. pp. 297-300. 